\title{
Students' Attitude Scale towards University Education: Validity and Reliability
}

\author{
Yucel Gelisli ${ }^{1, *}$, Lazura Kazykhankyzy $^{2}$ \\ ${ }^{1}$ Department of Educational Sciences, Gazi Faculty of Education, Gazi University, Emniyet Mahallesi/ Bandırma Caddesi/ Bosna \\ Binası No: 6/31, 06500/ Yenimahalle/ Ankara, Turkey \\ ${ }^{2}$ Khoja Akhmet Yassawi International Kazakh-Turkish University, B. Sattarhanov Caddesi No: 29, Turkistan, Kazakhstan
}

Received November 14, 2020; Revised January 21, 2021; Accepted January 28, 2021

\section{Cite This Paper in the following Citation Styles}

(a): [1] Yucel Gelisli, Lazura Kazykhankyzy, "Students' Attitude Scale towards University Education: Validity and Reliability," Universal Journal of Educational Research, Vol. 9, No. 3, pp. 466-478, 2021. DOI: 10.13189/ujer.2021.090306.

(b): Yucel Gelisli, Lazura Kazykhankyzy (2021). Students' Attitude Scale towards University Education: Validity and Reliability. Universal Journal of Educational Research, 9(3), 466-478. DOI: 10.13189/ujer.2021.090306.

Copyright $\bigcirc 2021$ by authors, all rights reserved. Authors agree that this article remains permanently open access under the terms of the Creative Commons Attribution License 4.0 International License

\begin{abstract}
The aim of the present study is to develop a valid and reliable measurement tool to determine students' attitudes towards university education. The sample of the study consisted of students enrolled in various teacher education programs of Gazi Education Faculty, Gazi University. A total of 556 students participated in the study. The data collected from 233 students were used for exploratory factor analysis, whereas 323 students' data were used for confirmatory factor analysis. Firstly, the items were created to compile an item pool and relevant academic staffs were asked to evaluate face and content validity of the scale. Then, the draft scale was applied to the sample and exploratory factor analysis (EFA) was performed to determine the factor structure of the scale. As a result of EFA, the scale comprised of 19 items grouped onto three factors was developed. Moreover, to test the three-factorial structure of the scale confirmatory factor analysis (CFA) was accomplished. The results of CFA confirmed the three-factorial structure of the scale. Finally, reliability analysis results indicated that the internal consistency coefficients for the whole of the students' attitudes towards university education scale and three subscales were .906; .835; .872; and .796.
\end{abstract}

Keywords Attitude, Attitude towards University Education, Attitude Scale, Attitude Scale towards University Education

\section{Introduction}

The term attitude is regarded as a very difficult construct to describe since it cannot be directly observed. Attitude is an emotional predisposition for a person to act in some way toward another person, object or idea [1]. Thus, it is considered to be one of the main factors that influence human behavior [2], [3]. According to Gardner [4] attitude is "an evaluative reaction to some referent or attitude object on the basis of the individual's beliefs or opinions about the referent" (p. 9). As Kpolovie, Joe \& Okoto[5] argue attitude is a consistent trend towards a positive or negative response to a particular subject or social object being measured. Attitude is affected by personal opinions and these opinions are formed through personal life experiences and education [1].

There are three structural components of attitude: cognitive, emotional, and behavioral, which is known as the ABC model or three component model of attitude [6]. That is to say, attitudes are formed by means of cognitive, affective and behavioral responses towards the attitude objects [7]. The cognitive component relates to the individual's thoughts, knowledge and beliefs about the attitude object. The affective component involves emotions and evaluations of the individual about the attitude object; and the behavioral component is about how our attitude affects our actions and leads our behavior [8], [3], [6]; [9], [10].

\subsection{Attitude towards Education and Learning}

Education is a process of socialization and educational institutions are important socialization tools for children and youth [11]. They help to organize students' behaviors 
through a series of rules, socially desired behaviors, rewarding systems, teaching activities, memorial days and ceremonies, teachers' attitudes towards students, the socio-cultural environment and peer interactions.

According to Lewy [12], educational institutions are places where students acquire attitudes and values from daily experiences. Lewy [12] was among the first who proposed the concept "attitude toward education" and defined it as the subject's behaviors, the expression of his/her feelings regarding the educational environment and experiences, as favorable or unfavorable. So that educational institutions help students to acquire emotions, thoughts and orientations through positive or negative experiences.

Attitude towards education is the way the student perceives his/her attendance of educational institutions [13]. Attitudes toward education are developed by interaction of students with different components of the system such as environment, curriculum, teachers and peers.

Chambers [14] states that attitude toward education composes of a set of values that are brought by a student to the learning environment. Moreover, personal psychological factors such as goals, self-efficacy, and interest in learning, competence, and motivation play an important role in developing a positive attitude of students toward education and learning [5], [15], [13]. In turn, Candeias, Rebelo \& Oliverra [16] state that socio-demographic factors such as ethnicity, religious affiliation, marital status, household, employment, and income, as well as personal characteristics are also determinant factors predicting students' attitudes towards education and learning. Candeias \& Rebelo [17] revealed that the socio-economic levels of families and their positive perspectives on education affect the positive attitudes of students towards learning. Similarly, Çelebi \& Çopur [18] concluded that the attitudes of students towards learning are affected by the family's interest in education.

The researches highlight the importance of attitudes towards school and learning as an important predictor of academic success [10], [19]. A positive relationship between students' attitudes towards school and academic achievement was found in many previous studies [10], [19], [20], [21], [22], [23], [24], [25], [26]. According to Verešová \& Malá [10] children who have positive attitudes towards school demonstrated more positive learning outcomes and academic achievements.

Moreover, different research studies investigating the relationship between attitude towards school and other factors related to school have been conducted up to now. For example, Argon \& Y1lmaz [27] conducted a research study to determine the relationship between high school students' attitudes towards school and their views on peer relationships. In their research, "School Attitude Scale" and "Peer Relations Scale" were used as data collection tools. As a result of the research, it was determined that students' perceptions of peer relations were at a medium level and their attitudes towards school were at a low level. In this study, it was found that high school students' attitudes towards school were low.

Another study found a positive relationship between attitude towards school and academic achievement. In the study conducted by Balkıs \& Arslan [28], it was obtained that the students who have positive attitude towards teacher and school, who have high motivation level and goals, have higher academic success.

Some students have negative attitudes towards school. Those students who have a negative attitude towards school are more likely to drop out, have lower academic grades, and are at risk of developing a number of other school-related problems [19].

\subsection{Students' Attitudes toward Higher Education}

Nowadays higher education is of crucial importance since it promotes social and economic development of the country. It increases individual's depth of knowledge so that leads to self-development, whereas self-development of people leads to social and economic development [29].

Since students are the most important component of higher education, it is important to know the attitudes, beliefs and needs of students in order to assess the quality of education in the universities [30], [31].

Different research studies to date explored the attitudes of the students towards secondary or high schools [10], [19], [20], [21], [22], [23], [24], [25], [26], [28]; but there is still a lack of research on students' attitudes toward university education, hence a lack of reliable and valid instruments to measure students' attitudes toward a university education.

Therefore, the purpose of this study is to develop a reliable and valid measuring tool for studying students' attitudes towards university education.

\section{Materials and Methods}

\subsection{Research Model}

In this research study, a survey model as a type of quantitative research design was used to develop a valid and reliable instrument to measure students' attitudes toward university education.

\subsection{Scale Development Sample}

The study group consisted of the students from various teaching programs enrolled in Gazi University Gazi Education Faculty in 2018-2019 academic year and was chosen by random sampling method. 
There are different opinions about the sample size in the literature regarding the scale development process. Field [32] considered 300 participants as sufficient, while other researchers Bryman [33], MacCallum [34], Tavşancıl [35] stated that the number of items should be at least five to ten times. In the present study, a total of 233 students from eleven different teaching programs at Gazi Education Faculty participated in the study. This number of participants is approximately six times the 38 items in the experimental draft scale form. Therefore, the sample size was assessed as sufficient enough to develop the scale according to the literature [34]. The distribution of students by the year of study is presented in Table 1 .

Table 1. Distribution of students according to grades

\begin{tabular}{cccc}
\hline Sample & Grade & f & $\mathbf{\%}$ \\
\hline \multirow{4}{*}{ Exploratory factor analysis } & $1^{\text {st }}$ year students & 82 & 35,2 \\
\cline { 2 - 4 } & $2^{\text {nd }}$ year students & 83 & 35,6 \\
\cline { 2 - 4 } & $3^{\text {rd }}$ year students & 20 & 8,6 \\
\cline { 2 - 4 } & $4^{\text {th }}$ year students & 34 & 14,6 \\
\cline { 2 - 4 } & Unresponsive & 14 & 6,0 \\
\cline { 2 - 4 } Confirmatory factor analysis & Total & 233 & 100 \\
\hline & $1^{\text {st }}$ year students & 163 & 50,5 \\
\cline { 2 - 4 } & $2^{\text {nd }}$ year students & 74 & 22,9 \\
\hline & $4^{\text {th }}$ year students & 30 & 9,3 \\
\cline { 2 - 4 } & Total & 36 & 17,3 \\
\hline General Total & & 556 & 100 \\
\hline & & & \\
\hline
\end{tabular}

As presented in Table 1, a total of 556 students participated in the study. The data collected from 233 participants were used for exploratory factor analysis. $35.2 \%$ of participants were the first-year students, whereas $35.6 \%$ the second-year, $8.6 \%$ the third-year and $14.6 \%$ the fourth-year students. 14 students $(6 \%)$ provided invalid responses.

The data collected from 323 participants were used for confirmatory factor analysis. The majority were the first-year students $(50.2 \%)$, whereas $22.9 \%$ the second-year, $17.3 \%$ the fourth-year and $9.3 \%$ the third-year students.

Following, the distribution of students according to gender is indicated in Table 2.
Table 2. Distribution of students according to gender

\begin{tabular}{cccc}
\hline Sample & Gender & $\mathrm{f}$ & $\%$ \\
\hline \multirow{3}{*}{ Exploratory } & Female & 177 & 76 \\
factor analysis & Male & 45 & 19,3 \\
& Unresponsive & 11 & 4,7 \\
\cline { 2 - 4 } & Total & 233 & 100 \\
\hline \multirow{2}{*}{ Confirmatory } & Female & 78 & 24,1 \\
factor analysis & Male & 245 & 75,9 \\
\cline { 2 - 4 } & Total & 323 & 100 \\
\hline
\end{tabular}

As it can be seen from table 2, among the responses of the participants used for exploratory factor analysis, 177 were females which composed $76 \%$ of the sample and 45 were male participants which were around $19 \%$, whereas 11 participants out of 233 which represents $4.7 \%$ of responses were found invalid. Almost $76 \%$ of participant responses used for confirmatory factor analysis were males, whereas only $24 \%$ were females.

\subsection{Scale Development Process}

The ability to measure attitudes depends on how it is defined. In developing an attitude scale, the most important thing is to make a decision on what object or situation the attitude is going to be measured. This decision is important for attitude scales related to emotions and reaction tendencies in order to evaluate individuals' attitudes [35], [36].

Researchers have long been using their own report scales in measuring attitude, which directly asks a participant to evaluate an attitude object by giving a numerical response to one or more items [37]. One of the most widely used scale types to date is Rensis Likert's "scaling with grading sums" model. This type of model is considered to be more economical than other models in terms of scale creation operations. In the Likert type scales, the reactions of individuals whose attitudes will be measured are assessed to the various expressions [38].

In practice, a researcher using Likert's outlined grading method [38] starts by developing an item pool, in other words creating a large number of items that are intuitively related to the attitude object, such as expressions of belief [39]. The participant who takes the attitude scale shows to what extent $\mathrm{s} / \mathrm{he}$ agrees with each particular expression given instead of marking the expressions s/he has adopted. In the present research, the instrument development process was followed in six stages, as presented table 3 . 
Table 3. Developmental process of the scale

\begin{tabular}{|c|c|c|c|c|c|}
\hline Stage 1 & Stage 2 & Stage 3 & Stage 4 & Stage 5 & Stage 6 \\
\hline $\begin{array}{l}\text { Relevant literature } \\
\text { related to the attitude } \\
\text { toward university } \\
\text { education was } \\
\text { thoroughly reviewed. A } \\
\text { draft form consisting of } \\
36 \text { items of Likert type } \\
\text { and three interview } \\
\text { questions were prepared } \\
\text { for the preliminary trial. }\end{array}$ & $\begin{array}{l}\text { The preliminary } \\
\text { draft form was } \\
\text { applied to } 40 \\
\text { students of the } \\
\text { education faculty. A } \\
\text { new draft form } \\
\text { consisted of } 61 \\
\text { items was prepared } \\
\text { with the data } \\
\text { obtained after the } \\
\text { examinations. }\end{array}$ & $\begin{array}{l}\text { Expert opinion was } \\
\text { taken for the } 61 \text { draft } \\
\text { forms prepared for the } \\
\text { scale, in order to } \\
\text { evaluate the scale } \\
\text { items on the clarity, } \\
\text { relevancy and } \\
\text { conciseness of the items. } \\
\text { Following necessary } \\
\text { arrangements were } \\
\text { made in the items. }\end{array}$ & $\begin{array}{l}\text { In order to } \\
\text { determine the scope } \\
\text { validity of the scale, } \\
\text { the draft form of the } \\
\text { scale was applied to } \\
\text { the expert group } \\
\text { consisted of } 10 \\
\text { experts. }\end{array}$ & $\begin{array}{l}\text { The scope } \\
\text { validity of the } \\
\text { form including } \\
38 \text { items was } \\
\text { determined by } \\
\text { applying to a } \\
\text { sample group of } \\
233 \text { students. }\end{array}$ & $\begin{array}{l}\text { Finally exploratory } \\
\text { factor analysis was } \\
\text { conducted to the } \\
\text { data in order to test } \\
\text { the structure validity } \\
\text { of the scale and to } \\
\text { specify the } \\
\text { dimensions of the } \\
\text { scale. Furthermore, } \\
\text { confirmatory factor } \\
\text { analysis was } \\
\text { conducted by } \\
\text { implementing the } \\
\text { scale to } 323 \\
\text { students. }\end{array}$ \\
\hline
\end{tabular}

\subsection{Preparation Steps of Draft Scale Form for Piloting}

Firstly, the relevant literature related to the attitude towards university education was thoroughly reviewed. In the second stage, a draft scale form consisting of 36 items in the five-choice Likert type and three open-ended questions was prepared. The draft scale form was applied to 40 senior year students of the Education Faculty. By analyzing the answers obtained from the pre-application, and considering participants suggestions 23 more items were added to the draft. The items were created according to three components of attitude: cognitive, affective and behavioral. Following, the draft form was examined by three experts and corrections were done in line with the expert's suggestions. As a result, the scale draft form consisted of 61 items (40 positive and 21 negative items) was prepared for piloting.

In order to determine whether the items included in the draft scale is able to measure attitudes towards school, it was tested based on experts' opinions. Content validity was calculated to determine whether each item on the scale will measure what it intends to measure. The scale's content validity must be determined before performing statistical factor analysis, reliability analysis and other statistical analysis on the measurement tool [40]. Content validity of the scale can be done with different methods. These methods are determined based on the opinions of the experts or the equivalent scale form by looking at the correlation coefficient (predictive power) between them [41]. To ensure the content validity of the scale, the draft scale form was examined by ten faculty members in the field of Educational Sciences in order to determine the suitability of the items, the content validity rates and the content validity index of the scale.

Lawshe [42] technique was used to measure the content validity ratio of the scale. For the application of this technique, an expert group composed of five to forty experts is required. In this study, ten experts from the field of educational sciences were selected to judge the draft instrument. According to Yurdugül [43], validity ratio higher 0.60 is considered acceptable. After the experts filled in all the forms, the opinions of the experts were combined in a single form by specifying which of the possible options for each item was summed. Content validity ratio (CVR) and content validity index (CVI) of the scale were calculated for each item [44]. Academicians who are experts in their field specified their opinions and suggestions for each item. It required the expert to mark "acceptable" if $s /$ he considers each item appropriate to measure what it intends to measure. If the item is within the scope of the subject but needs to be edited or changed, they required to mark "needs correction", and indicate their suggestions; and if a particular item seems unacceptable to the expert he should mark "unacceptable" and indicate reasons. Table 4 represents the item coverage validity scale and content validity index of the scale.

As seen from Table 4, the result of the analysis indicated that item content validity criteria were determined for ten experts according to Lawshe [42] technique. 23 items with the content validity ratio lower than the item content validity criterion $(\mathrm{N}=10, \mathrm{CVR}=$ 0.62 ) were excluded from the scale. Finally, the draft form for piloting was obtained in which CVR was ranged between 0.82-1.00 and CVI was determined as 0.868 . 
Table 4. Content validity ratios of the draft scale calculated according to Lawshe technique

\begin{tabular}{|c|c|c|c|c|c|c|c|c|c|c|c|}
\hline Scale items & *CVR & Scale items & CVR & Scale items & CVR & $\begin{array}{l}\text { Scale } \\
\text { items }\end{array}$ & CVR & $\begin{array}{l}\text { Scale } \\
\text { items } \\
\end{array}$ & CVR & $\begin{array}{l}\text { Scale } \\
\text { items }\end{array}$ & CVR \\
\hline 1 & 1 & 8 & 1 & 15 & 1 & 22 & 1 & 29 & 0,8 & 36 & 0,8 \\
\hline 2 & 0,8 & 9 & 0,8 & 16 & 1 & 23 & 1 & 30 & 0,8 & 37 & 0,8 \\
\hline 3 & 0,8 & 10 & 0,8 & 17 & 0,8 & 24 & 08 & 31 & 0,8 & 38 & 0,8 \\
\hline 4 & 1 & 11 & 1 & 18 & 1 & 25 & 0,8 & 32 & 0,8 & & \\
\hline 5 & 0,8 & 12 & 1 & 19 & 0,8 & 26 & 0,8 & 33 & 0,8 & & \\
\hline 6 & 0,8 & 13 & 1 & 20 & 0,8 & 27 & 0,8 & 34 & 0,8 & & \\
\hline 7 & 1 & 14 & 0,8 & 21 & 0,8 & 28 & 1 & 35 & 0,8 & & \\
\hline$* * \mathrm{CVI}$ & ,868 & & & & & & & & & & \\
\hline
\end{tabular}

*Content validity ratio (CVR) **Content Validity Index (CVI)

In accordance with the format of the Likert type grading scale, the responses were ranged as $1=$ totally disagree, $2=$ disagree; $3=$ partially agree; $4=$ agree; $5=$ totally agree. Negative items were scored by reverse coding. The scores were distributed as given in Table 5, according to the level of agreement:

Table 5. Distribution of scores in the scale

\begin{tabular}{cc}
\hline Score distribution & Level of agreement \\
\hline $1.00-1.80$ & Totally disagree \\
$1.81-2.60$ & Disagree \\
$2.61-3.40$ & Partially agree \\
$3.41-4.20$ & Agree \\
$4.21-5.00$ & Totally agree \\
\hline
\end{tabular}

\subsection{Data Analysis}

In the process of developing a scale, the main thing is to determine the validity of the scale, by implementing content and construct validity analyses. Content validity of the scale is the ability of an instrument to measure what it intends to measure. In other words, the peculiarity of the measuring instrument is its exact measuring power [44], [45]. That is why content validity is of crucial importance.

Following, it is required to assess the construct validity of the scale. Construct validity is measured by applying exploratory factor analysis (EFA) to the data, in order to calculate the interrelationships among items and exclude inadequate items from the scale. In the process of EFA, item total correlations were calculated for each item according to the total scores of the group, in which the items were studied in terms of their ability to be consistent and to determine and stimulate reactions that are desirable to observe without causing undesirable reactions. Items indicated high correlations with the total scale scores were retained and others were discarded. The construct validity of the scale was performed in three stages: factor analysis, item total correlation and item discrimination analysis [35].

Before implementing factor analysis to the data, Kaiser-Meyer-Olkin (KMO) coefficient and Barlett
Sphericity test were performed in order to identify whether the data were suitable for factor analysis or not [46].

After the data were found suitable for factor analysis, exploratory factor analysis was performed to analyze the construct validity and factor structure of the scale. Principal component analysis (PCA) was used as the factoring technique in EFA. By performing factor analysis, it was aimed to determine whether the draft scale consisting of 38 items was a single or multi-factored one. Preliminary, PCA was conducted without interfering to the number of factors and Varimax rotation technique was applied to reveal the sub-factors of the scale [46], [47], [48]. In the analysis, factor loadings, explained variance ratios and slope graph of the common factor variance of the factors on each variable were examined. The factor loadings of the items were chosen as 0.30. Item discrimination indexes were calculated to each item to justify the usefulness and effectiveness of each item in the scale.

As a final step, confirmatory factor analysis was performed to test the structure validity of the instrument obtained by the exploratory factor analysis. CFA tests specific hypotheses about structure and relations between the latent variables that underlie the data [32]. LISREL 8.7 program was used for Confirmatory Factor Analysis. Finally, reliability analysis was accomplished to determine the internal consistency of the items and sub dimensions.

\section{Results}

In order to present the findings in more systematic way, this section was divided into three parts with the following headings: evaluating the suitability of the data for factor analysis, determining the construct validity and verification of the reliability of the draft scale.

\subsection{Suitability of Data for Exploratory Factor Analysis}

In order to determine the sub-dimensions of the designed scale and what qualities it measures, the 
construct validity must be assessed [35]. In this study, explanatory factor analysis was conducted to determine the construct validity of the draft scale. Kaiser-Maiser-Olkin and Barlett test was used to determine the suitability of the data for explanatory factor analysis.

Before the Kaiser-Maiser-Olkin and Barlett test was conducted, a reliability analysis was performed in order to assess the internal consistency of the scale. The Cronbach alpha reliability coefficient of the scale was found to be .931 . Following, the item total correlation of the scale was calculated, and three items $(19,25$ and 37) with factor loads less than .30 were removed from the scale. The item total correlation of the scale was calculated one more time in order to ensure that there were no left items with factor loads less than .30. However, no such items were found. Finally, 35 items were tested for factor analysis. Table 6 represents the results of KMO and Bartlett's Test.

Table 6. KMO and Bartlett's test results

\begin{tabular}{ccc}
\hline \multicolumn{2}{c}{ Kaiser-Meyer-Olkin Measure of Sampling } &, 907 \\
\hline & Adequacy. & 4239,225 \\
$\begin{array}{c}\text { Bartlett's Test of } \\
\text { Sphericity }\end{array}$ & df & 595 \\
& Sig. &, 000 \\
\hline
\end{tabular}

As seen from Kaiser-Meyer-Olkin (KMO) coefficient and Bartlett Sphericity test results presented in Table 6, KMO (Kaiser Meyer Olkin) was found 0.907 and Bartlett's Sphericity test result (Bartlett's test of Sphericity) was calculated as $\mathrm{x} 2=4239,225$ and $\mathrm{p}<.00$. Tabachnick \& Fidell [49] stated that for factor analysis, the KMO value which ranged between 0 and 1 should be minimum .60. According to Kaiser [50] and Cerny \& Kaiser [51], for factor analysis, the KMO value must be .50 and higher, and the Barlett Sphericity test result must be statistically significant. So, it may be concluded that $\mathrm{KMO}$ value higher than .60 is considered to be acceptable whereas the value higher than .70 is considered as perfect for factor analysis. The results indicated that the data obtained in this study are statistically significant and normally distributed. Since the Barlett Sphericity test is used to check if the data came from the multivariate normal distribution, the results confirmed that the data obtained in this study meet the requirements in terms of both criteria required for factor analysis [35], [46], [47], [48], [52], [53], [54], [55]. So, the results of the analysis showed that the data are highly eligible for factor analysis.

One of the most frequently used methods for factor analysis is the "Principal Components Analysis Method". The aim of the Principal component analysis is to determine the number of factors that best explain the relationship between the scale and the sub-dimensions.
The factor analysis process involves two opposite situations: to identify the least possible number of factors and the highest explained variance [53], [56]. Tabachnick \& Fidell [49] suggested that researchers should try different numbers of factors in order to find the most suitable factor number with an exploratory approach. They also stated that such techniques as Kaiser Criterion, Scree test, Joliffe criterion, disclosed variance criterion and Parallel analysis can be used to determine the number of factors[35], [48].

Kaiser Criterion Technique is the most frequently used technique in factor determination. In this technique the factors which Eigen value is 1 and greater than 1 are investigated [48], [54]. Table 7 represents the results of the Principal Component Analysis.

Although it is found strong evidence that the scale is one-dimensional, according to the principal components analysis, as it is shown in table 7, the Varimax vertical rotation method was applied to look at the factor structure of the items. As a result, it was seen that 35 items in the scale were grouped in seven factors with an eigenvalue greater than 1 . The first factor explained $34.398 \%$ of the total variance; the second factor explained $7.094 \%$, the third factor $5.907 \%$, and these three factors explained $47.400 \%$ of the total variance.

Since it was difficult to associate the factors of multi-factor scales with the theoretical basis [57], it was decided to support the determined factor structure of the scale with scree plot. Scree plot is one of the reliable methods used to determine the factor structure of the scale, especially in scale development studies with a sample larger than 200 [32]. In scree plots, high acceleration, rapid decreases or sudden changes are used to determine the number of factors [32], [52]. Scree plot chart of the scale is given in figure 1 .

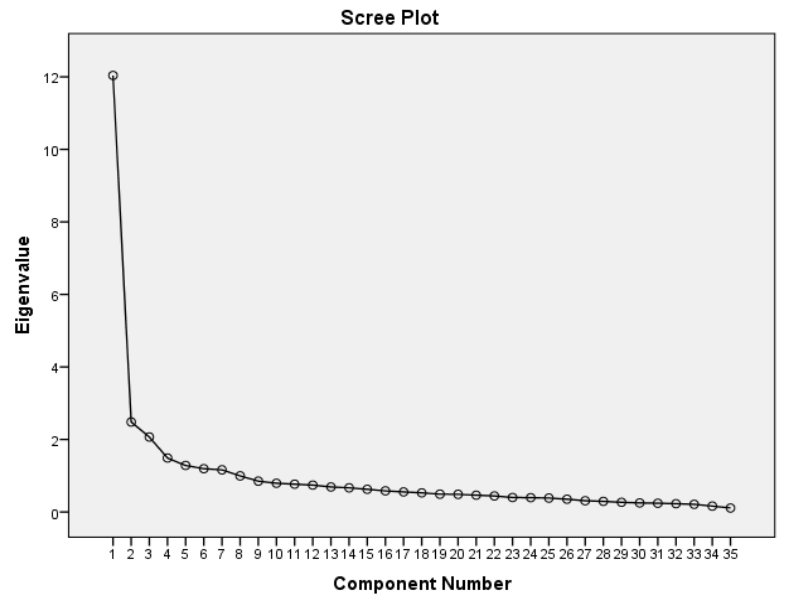

Figure 1. Scree plot chart of the scale 
Table 7. The Results of the principal component analysis

\begin{tabular}{ccccccc}
\hline \multirow{2}{*}{ Component } & \multicolumn{3}{c}{ Initial Eigenvalues } & \multicolumn{3}{c}{ Extraction Sums of Squared Loadings } \\
\cline { 2 - 7 } & Total & $\begin{array}{c}\text { \% of } \\
\text { Variance }\end{array}$ & $\begin{array}{c}\text { Cumulative } \\
\%\end{array}$ & Total & \% of Variance & $\begin{array}{c}\text { Cumulative } \\
\%\end{array}$ \\
\hline 1 & 12,039 & 34,398 & 34,398 & 12,039 & 34,398 & 34,398 \\
2 & 2,483 & 7,094 & 41,492 & 2,483 & 7,094 & 41,492 \\
3 & 2,068 & 5,907 & 47,400 & 2,068 & 5,907 & 47,400 \\
4 & 1,488 & 4,252 & 51,652 & 1,488 & 4,252 & 51,652 \\
5 & 1,283 & 3,665 & 55,316 & 1,283 & 3,665 & 55,316 \\
6 & 1,193 & 3,409 & 58,725 & 1,193 & 3,409 & 58,725 \\
7 & 1,162 & 3,321 & 62,045 & 1,162 & 3,321 & 62,045 \\
\hline
\end{tabular}

When the graph (Figure 1) was examined, it was seen that the first sudden change or high acceleration decline is in the third factor. It was determined that the factors after the third factor overlap and their contribution to the total variance is also low. Following, it was decided to group the items into three factors by comparing the total variance and eigenvalues explained for the items of the scale with the Scree plot chart. Although the 34\% explanation of the total variance of the first factor shows that the scale may be one-dimensional, the three-factor structure's explanation about $50 \%$ of the total variance supports the decision that it would be more appropriate to have the three-factor scale.

To simplify and clarify the data structure [53], [58], the principal components analysis was repeated using the Varimax vertical rotation method. Items with factor loading and total variance value less than 0.30 , as well as the items with item total correlation less than 0.30 and overlapping items which take place in two factors with the difference in load values less than 0.10 were excluded from the scale.

After the application of Varimax vertical rotation method, the distribution of the items in the scale according to factors, item total correlations, total variance values and factor loading values were examined and 7 items $(15,16$, $18,21,23,26,31)$ were excluded from the scale. Following, Varimax vertical rotation method was performed again and six factors which Eigenvalues were above 1 established. However, after the fourth factor, there was a bounce in the Eigenvalue and three factors explained $50.635 \%$ of the scale. Accordingly, it was decided to keep the scale with three factors. After determining that the scale has three-factor structure, it was looked at the item total correlation values. Items with factor loadings less than .30 and showing variance $(8,11$, $12,14,18,22,24,27$ and 33) were excluded from the scale. Finally, the data were rerun again with three factors, the results of which are given in table 8 .

As it is seen from table 8, the result of Varimax vertical rotation with three factors revealed that three factors explained $58.185 \%$ of the scale.

As a result of exploratory factor analysis, a total of nineteen items $(3,7,8,11,12,14,15,16,18,19,21,22$, $23,24,25,27,31,33,37)$ with common variance values, factor loads, item total correlations under .30 and those showed ambivalence by taking place in more than one factor removed from the draft scale. After the analysis was conducted, the scale consisted of 19 items was grouped under three sub-dimensions established. The first sub-dimension of the scale consisted of 8 items $(6,13,20$, $26,29,30,32$ and 38 ) and explained $37.856 \%$ of the total variance. The factor loadings of the items in this dimension varied between .602 and 803 coefficients. The second sub-dimension consisted of 7 items $(1,2,4,5,9$, 10 and 17$)$ and explained $11.518 \%$ of the total variance. The factor loadings of items in this factor ranged between .613 and .815 . The third sub-dimension consisted of 4 items $(28,34,35$ and 36) and explained $8.810 \%$ of the total variance. The factor loadings of items in this dimension ranged from .557 to .849 . It was observed that the total variances of the items in the whole scale varied between .557 and .849 . In Table 9 the factors of the scale, factor loadings, item total correlations, arithmetic mean, standard deviations and t-test results for the $27 \%$ of the total group are given. (see Table 9). 
Table 8. Total variance and Eigenvalues explained for the items of the scale

\begin{tabular}{|c|c|c|c|c|c|c|c|c|c|}
\hline \multirow[b]{2}{*}{ Compenet } & \multicolumn{3}{|c|}{ Initial Eigenvalues } & \multicolumn{3}{|c|}{ Extraction Sums of Squared Loadings } & \multicolumn{3}{|c|}{ Rotation Sums of Squared Loadings } \\
\hline & Total & $\begin{array}{c}\% \text { of } \\
\text { Variance }\end{array}$ & Cumulative \% & Total & $\begin{array}{c}\% \text { of } \\
\text { Variance }\end{array}$ & Cumulative $\%$ & Total & $\begin{array}{c}\% \text { of } \\
\text { Variance }\end{array}$ & Cumulative $\%$ \\
\hline 1 & 7,193 & 37,856 & 37,856 & 7,193 & 37,856 & 37,856 & 4,292 & 22,591 & 22,591 \\
\hline 2 & 2,188 & 11,518 & 49,375 & 2,188 & 11,518 & 49,375 & 4,088 & 21,516 & 44,107 \\
\hline 3 & 1,674 & 8,810 & 58,185 & 1,674 & 8,810 & 58,185 & 2,675 & 14,078 & 58,185 \\
\hline
\end{tabular}

Extraction Method: Principal Component Analysis.

Table 9. Factors of the scale, factor loadings, item total correlations, arithmetic mean, standard deviations of items, $27 \%$ group t-test results.

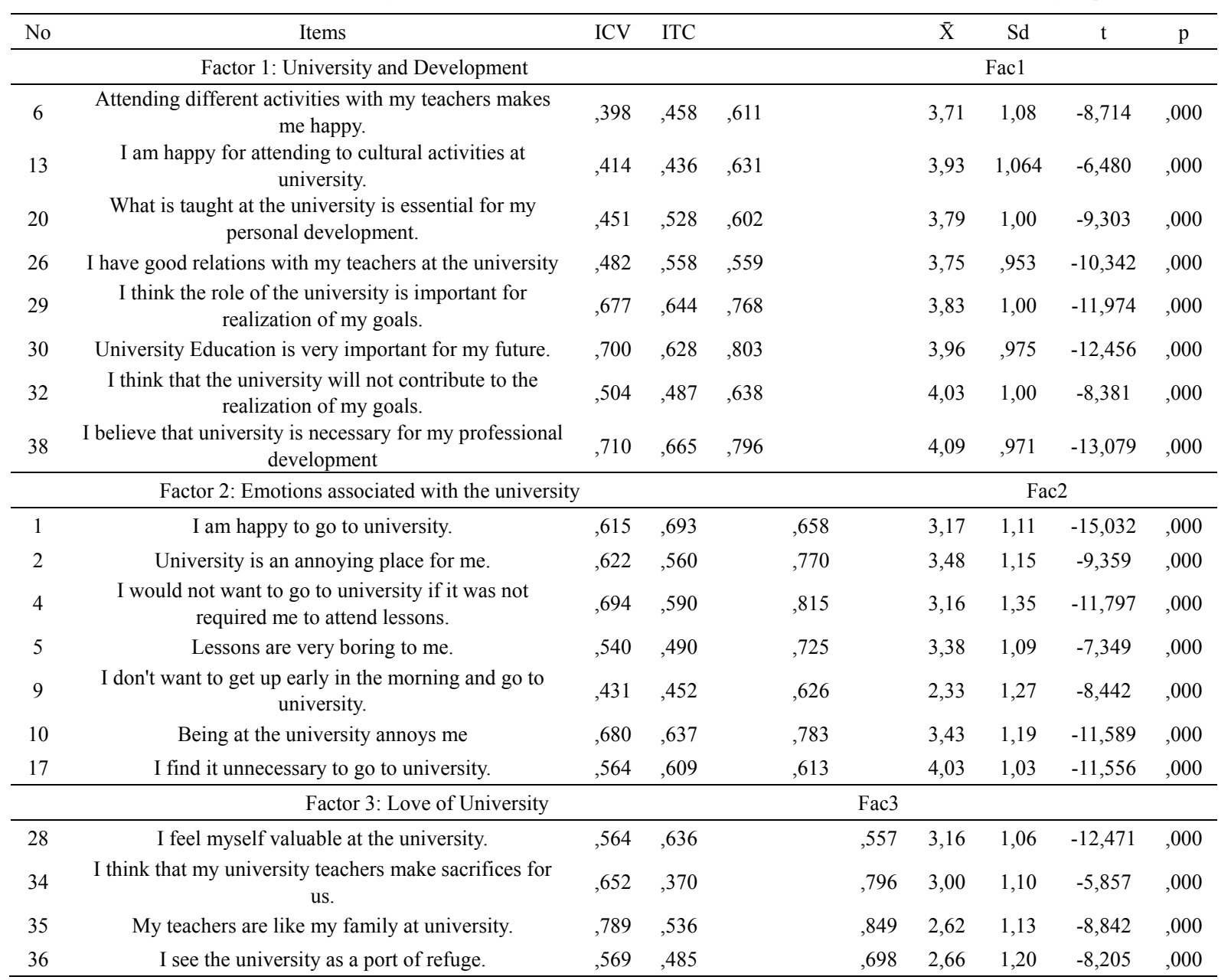

*ITC: Item Total Correlation *ICV: Item Common Variance

Finally, to determine how adequate it is to differentiate individuals in terms of the characteristics measured by the scale, independent sample t-test was conducted by comparing the upper group consisting of $27 \%$ of participants with the highest scores and the lower group consisting of $27 \%$ of participants with the lowest scores. This index is used to determine the effectiveness of each item in discriminating between high and low scores on the whole scale. The values for the item discrimination index are ranged between -1.00 and 1.00 . The value higher than .30 is considered acceptable [46], [52]. However, the higher the discrimination value of the item the more
*All $\mathrm{t}$ values at the level $\mathrm{p}<0.001$ are significant

effective it is. According to the data obtained, the total correlations of the item were greater than .30; the t-test results revealed a significant difference $(p<.001)$ between the upper and lower groups. According to these values, it can be said that each item in the Attitude Scale of Students towards University Education differentiates students' attitudes towards university education. When the items of the scale were examined, it was found that 9 items belong to affective component, 7 items belong to cognitive component and 3 items belong to behavioral component which supports $\mathrm{ABC}$ components of attitude. 


\subsection{Confirmatory Factor Analysis}

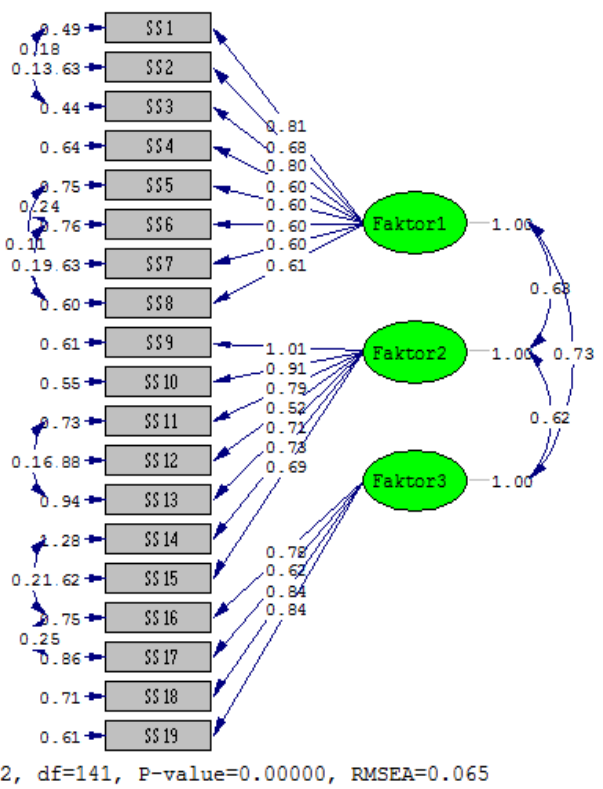

Chi-Square $=333.62, \mathrm{df}=141, \mathrm{P}-\mathrm{value}=0.00000, \mathrm{RMSEA}=0.065$

Figure 2. Path diagram of the confirmatory factor analysis of students' attitudes towards university education scale

To determine the suitability of the scale structure in the context of model fit indices elicited through exploratory factor analysis Confirmatory factor analysis (CFA) was performed. As a result of the confirmatory factor analysis, it was observed that the model fit values of the thirteen items in the scale were not acceptable. Thus, it was decided to improve the modification indexes. While improving, variables that reduce compliance were determined and new covariance was created for those with higher covariance among the values. The new model obtained is presented in Figure 2.

Acceptable values for the fit indices were provided in the fit index calculations renewed after the confirmatory factor analysis modification procedures of the scale and are shown in Table 10.

Table 10 shows the result of the analysis, according to which the modifications were made. Modification results are presented in Figure 2. With the help of confirmatory factor analysis, it was tested whether the sampling data confirmed to the original factor structure. Chi Square $(\chi 2)$, RMSEA, NFI, NNFI, CFI, GFI, and AGFI are the most commonly used statistical analysis in model data fit structure. As a result, the following values were determined: RMSEA, $0.065 ; \chi 2 / \mathrm{df}=236 ; \mathrm{SRMR}=.058$; $\mathrm{NFI}=.95 ; \mathrm{NNFI}=.96 ; \mathrm{IFI}=.97 ; \mathrm{CFI}=.97 ; \mathrm{RFI}=.94$. It was found that these results were within the acceptable reference range.

In the confirmatory factor analysis, the chi-square fit test is expected to be between 2 and 3, the Mean Square Root of the Approximate Errors (RMSEA) value should not exceed 0.08; Comparative Fit Index (CFI, Comparative Fit Index) value must be above 0.85 or 0.95 ; Goodness of Fit Index (GFI, Goodness of Fit Index) value is expected to be high due to its similarity to $R 2$ in multiple regression.

Additionally, for values ranging from 0 to 1 , it is known that the Square Root (SRMR) value closest to zero is more suitable to the model. Moreover, the model with the smallest Akaike Information Criterion (AIC, Akaike Information Criterion), Consistent Akaike Information Criterion, and Expected Cross Validation Index (ECVI) value is said to be the closest model to reality.

The values of the model obtained as a result of the modification were found to be within acceptable limits. The evaluation of the fit of the model was made considering the reference values in table 10 [59], [60], [61], [62]. Therefore, the three-factor structure of the scale was confirmed.

Table 10. Fit index statistics for students' attitudes towards university education scale

\begin{tabular}{|c|c|c|c|c|}
\hline Fit Index & Good Fit & Acceptable Fit & Suggested New Model & Acceptable \\
\hline$\chi^{2}$ & & 333,62 & & \\
\hline$\chi^{2 / d f}$ & $0,00<\chi 2 / \mathrm{sd}<3,00$ & $3,00<\chi 2 / \mathrm{sd}<5,00$ & 2,366 & Good Fit \\
\hline P değeri & $0,05 \leq \mathrm{p} \leq 0,10$ & $0,01 \leq \mathrm{p} \leq 0,05$ & 0,000 & \\
\hline RMSEA & $0,00 \leq$ RMSEA $\leq 0,05$ & $0,05 \leq$ RMSEA $\leq 0,10$ & 0,065 & Acceptable \\
\hline RMR & $0,00 \leq \mathrm{RMR} \leq 0,05$ & $0,05 \leq \mathrm{RMR} \leq 0,10$ & 0,070 & Acceptable \\
\hline SRMR & $0,00 \leq \mathrm{SRMR} \leq 0,05$ & $0,05 \leq \mathrm{SRMR} \leq 0,10$ & 0,058 & Acceptable \\
\hline NFI & $0,95 \leq \mathrm{NFI} \leq 1,00$ & $0,90 \leq \mathrm{NFI} \leq 0,95$ & 0,95 & Acceptable \\
\hline NNFI & $0,97 \leq \mathrm{NNFI} \leq 1,00$ & $0,90 \leq \mathrm{NNFI} \leq 0,97$ & 0,96 & Acceptable \\
\hline CFI & $0,95 \leq \mathrm{CFI} \leq 1,00$ & $0,90 \leq \mathrm{CFI} \leq 0,94$ & 0,97 & Good Fit \\
\hline IFI & $0,95 \leq \mathrm{IFI} \leq 1,00$ & $0,90 \leq \mathrm{IFI} \leq 0,94$ & 0,97 & Good Fit \\
\hline GFI & $0,96 \leq \mathrm{GFI} \leq 1,00$ & $0,90 \leq \mathrm{GFI} \leq 0,95$ & 0,90 & Acceptable \\
\hline AGFI & $0,90 \leq \mathrm{AGFI} \leq 1,00$ & $0,85 \leq \mathrm{AGFI} \leq 0,90$ & 0,87 & Acceptable \\
\hline PGFI & $0,95 \leq \mathrm{PGFI} \leq 1,00$ & $0,50 \leq \mathrm{PGFI} \leq 0,95$ & 0,67 & Acceptable \\
\hline AIC Model & Independence $\mathrm{AIC}=$ & $431,62 \leq 6740,04$ & 485,42 & \\
\hline CAIC Model & Independence $\mathrm{CAIC}=$ & $665,72 \leq 6830,81$ & 665,72 & \\
\hline ECVI & 90 Percent Confidence Inter & val for ECVI $(1,19 ; 1,52)$ & 1,34 & \\
\hline
\end{tabular}


Table 11. Reliability analysis results of the scale and sub-dimensions

\begin{tabular}{|c|c|c|c|c|c|}
\hline Factors & $\mathrm{N}$ & Items no & $\overline{\mathrm{X}}$ & Variance Explained & Cronbach Alpha \\
\hline Factor 1: University and Development & 223 & $\begin{array}{c}6,13,20,26,29 \\
30,32,38\end{array}$ & 3,90 & $37,856 \%$ & ,835 \\
\hline $\begin{array}{c}\text { Factor 2: Emotions associated with the } \\
\text { university }\end{array}$ & 223 & $1,2,4,5,9,10,17$ & 3,29 & $11.518 \%$ & ,872 \\
\hline Factor 3: Love of University & 223 & $28,34,35,36$ & 2,86 & $8.810 \%$ & ,796 \\
\hline Total & 223 & & 3,45 & $58,185 \%$ & ,906 \\
\hline
\end{tabular}

\subsection{Reliability Analysis}

Finally, to determine the internal consistency of the scale, the Cronbach's alpha values were calculated for the entire scale and its three dimensions. The results are indicated in the Table 11.

Reliability analysis was conducted to identify whether the items are consistent with each other or not. When Table 11 was analyzed, it was revealed that the reliability coefficient of the first sub-dimension (University and Development) was calculated as $\alpha=0.835$, the second sub-dimension (Emotions associated with the university) as $\alpha=0.872$, and the third sub-dimension (Love of University) as $\alpha=0.796$. The reliability coefficient of the entire scale was calculated as $\alpha=0.906$.

Different opinions exist among researchers related to the scale reliability coefficient. Lui (63) stated that for the reliability of the scale, above 0.70 is acceptable. According to Özdamar (64), the reliability coefficient values between 0.80 and $0.90(0.80 \leq \propto \leq 1.00)$ are accepted as high reliability level. According to this criterion, the reliability coefficient of "Students' Attitude towards University Education" scale is quite high as it was calculated as $\alpha=0.906$, which means that the items in the scale are highly correlated with each other so that the scale is consistently reliable. Table 12 gives the results of correlation analysis.

Table 12. Correlation results between factors and total scale

\begin{tabular}{cccccccc}
\hline Factors & $\mathrm{N}$ & $\overline{\mathbf{X}}$ & $\mathrm{Sd}$ & $\mathrm{Fac} 1$ & $\mathrm{Fac} 2$ & $\mathrm{Fac} 3$ & $\mathrm{p}$ \\
\hline $\begin{array}{c}\text { Factor } \\
1\end{array}$ & 223 & 3,88 &, 72302 & ---- &, $496^{* *}$ &, $496^{* *}$ &, 000 \\
$\begin{array}{c}\text { Factor } \\
2\end{array}$ & 223 & 3,28 &, 88788 &, $496^{* *}$ & --- &, $436^{* *}$ &, 000 \\
$\begin{array}{c}\text { Factor } \\
3\end{array}$ & 223 & 2,86 &, 88905 &, $496^{* *}$ &, $436^{* *}$ & --- &, 000 \\
Total & & 3,45 &, 66588 &, $840^{* *}$ &, $841^{* *}$ &, $722^{* *}$ &, 000 \\
\hline
\end{tabular}

$* * \mathrm{p}<.01$ Correlation is significant at the 0.01 level (2-tailed).

When the correlation coefficients between the independent factors and a whole scale were analyzed, the correlation between the first and the second factor was found to be $r=496$, between the first and the third-factor $r$ $=.496$, and between the second and the third factor was found to be $r=.436$ (see Table 12). These results indicated a medium level of positive correlations among three sub-dimensions of the scale. Moreover, the correlation between the first factor and the entire scale was found to be $\mathrm{r}=.840$, between the second factor and the entire scale $r=841$, and between the third factor and the entire scale $r$ $=.722$, which indicated a high level of correlation between the factors and the entire scale.

\section{Discussion and Conclusions}

The main purpose of the present study was to develop a valid and reliable measurement tool to determine students' attitudes towards university education. As the first step of the scale development process, CVR and CVI values of the total 61 items were determined in accordance with the expert opinions, based on Lawshe technique. As a result, 23 items with low content validity rate were removed from the draft scale. The draft scale consisted of 38 items was prepared for piloting and applied to 223 Education faculty students. Following exploratory factor analysis was performed to the obtained data. As a result of EFA, 19 items were eliminated from the scale. Finally, the scale included 19 items (13 positive and 6 negative items) grouped under three factors was reached.

The model fit test of the values and scale structure obtained for students' attitudes towards university education scale was evaluated by confirmatory factor analysis.

As a result of the first level confirmatory factor analysis of the scale, the fit indices were calculated as Chi-Square $\chi^{2}=333.62(\mathrm{Sd}=141, \mathrm{p} .=0.00), \chi^{2} / \mathrm{Sd}=2.36$, while the NCP value was found as 192.62. The scale's RMSEA value was 0.065 , SRMR value was 0.058 , GFI value was 0.90 , AGFI value was 0.87 , CFI value was 0.97 , and NFI value was 0.95 , NNFI value, 0.95 , RFI value was 0.94 , IFI value was 0.97 . When we looked at the results of the confirmatory factor analysis of the scale, it was seen that the adjustment values were above "sufficient level" and close to "excellent level". This shows that the fit indexes of the scale are at an acceptable level.

In the similar study conducted by Adigüzel [65] in secondary school in order to determine students' attitudes towards the school, the author developed the 21-item scale. The items were grouped under four main dimensions: Love, Value, Harmony and Trust. The overall internal consistency coefficient of the scale was found to be .860 .

In other scale development study conducted in Turkish context by Alic1 [21] to determine high school students' attitudes towards school, the author created a scale with 
20 items, of which 12 were positive and 8 were negative items. The three sub-dimensions were identified as "School as the Barrier of Personal Development", "School as the Supporter of Personal Development" and "School as a Missing Entity", respectively.

Conceptualizing attitudes as having affective (emotional) and cognitive (belief) bases has been one of the most popular means of classifying the different types of information upon which attitudes are based [66]. According to the related literature, it is seen that attitude towards school is about cognitive and social participation, teacher-student relations, students' characteristics and trends, school security and bullying experiences [67]. The items of the scale that developed in the present study to determine students' attitudes towards university education, therefore, include cognitive and social participation, teacher-student relations, student-student relations, and attitudes towards the physical structure of the school.

As a result of the validity and reliability analyses, "Attitude Scale of the Students towards University Education" was accepted as a valid and reliable instrument for measuring the attitudes of the students towards university education.

\section{Acknowledgments}

We are very grateful to experts for their appropriate and constructive suggestions to improve this template.

\section{REFERENCES}

[1] E. Hacieminoğlu. Elementary School Students' Attitude toward Science and Related Variables, International Journal of Environmental and Science Education, Vol. 11, No. 2, 35-52, 2016.

[2] I. Ajzen, M. Fishbein. Understanding attitudes and predicting social behavior, Englewood Cliffs NJ: PrenticeHall, 1980.

[3] M. Fishbein, I. Ajzen. Belief, Attitude, Intention, and Behavior: An Introduction to Theory and Research. Reading, MA: Addison-Wesley, 1975.

[4] R. C. Gardner. Social psychology and second language learning: the role of attitudes and motivation, London: Edward Arnold, 1985.

[5] P. J. Kpolovie, A. I. Joe, T, Okoto. Academic Achievement Prediction: Role of Interest in Learning and Attitude towards School. International Journal of Humanities Social Sciences and Education (IJHSSE), Vol. 1, No. 11, 73-100, 2014.

[6] M. Hogg, G. Vaughan., G. Social Psychology (4th edition), London: Prentice-Hall, 2005.

[7] A. H. Eagly, S. Chaiken, S. Attitude structure and function, The handbook of social psychology, Vol. 1, No. 2, 269-322,
1998.

[8] L. W. Anderson. Attitudes and their measurement. In J.P. Keeves. (Ed.), Educational research, methodology and measurement: An international handbook. New York, Pergamon Press, 1988.

[9] A. A. Tezbaşaran. Likert tipi ölçek geliştirme kılavuzu [Likert type scale development guide], Ankara: Türk Psikologlar Derneği Yayınları, 1997.

[10] M. Verešová, D. Malá. Attitude toward school and learning and academic achievement of adolescents, 7th International Conference on Education and Educational Conference, The European Proceedings of Social \& Behavioural Sciences EpSBS Published by Future Academy. (XV), 870-876, 2016.

[11] J. C. Brazzell. Education as a tool of socialization: Agnes Scott Institute and Spelman Seminary, 1881-1910, University of Michigan, 1991.

[12] A. Lewy. School Attitudes: General, In H. Husén \& T. Postlethwaite (Ed.), The International Encyclopedia of Education, 4408-4411. Oxford: Pergamon Press, 1986.

[13] A. Moè, F. Pazzaglia, P. Tressoldi, C. Toso. Attitude towards school, motivation, emotions and academic achievement, (Ed. Jonathon E. Larson. Educational Psycholog), pp, 259-273, Nova Science Publishers, Inc, 2009.

[14] G. N. Chambers. Motivating language learners, Vol. 12, Multilingual Matters, 1999.

[15] M. L. Maehr. Meaning and motivation: Toward a theory of personal investment, Research on motivation in education, Vol.1, No. 4, 115-144, 1984.

[16] A.A. Candeias, N. Rebelo, M. Oliveira, M. Student's attitutes toward learning and school-study of exploratory models about the effects of socio-demographics and personal attributes, In C. A. Shoniregun, \& G. A. Akmayeva (Eds.), Proceedings of the London International Conference on Education [CD-ROM], London, UK: Infonomics Society, 380-385, 2011.

[17] A. A. Candeias, N. Rebelo, N. Students, attitudes toward school, learning, competence and motivation - the effects of gender, contextual background, school failure and development, Investigación en Convivencia Escolarvariables relacionadas, GEU Editorial. pp. 547-554, 2010.

[18] M. Çelebi, D. K. Çopur. Determining the Relationship between Students' Attitudes towards School and Socioeconomic Structure of the Family: The Case of Niğde Province, International Journal of Society Researches, Vol. 13, No.19, 786-814, 2019. DOI: 10.26466/opus.590974.

[19] R. B. King, D.M. McInerney, F. A. Ganotice Jr, J. B. Villarosa. Positive affect catalyzes academic engagement: Cross-sectional, longitudinal, and experimental evidence, Learning and Individual Differences, Vol. 39, 64- 72, 2015.

[20] L. Ak, M. Sayil. Three different types of elementary school students' school achievements, perceived social support, school attitudes and behavior-adjustment problems, Educational Sciences: Theory \& Practice, Vol. 6, No. 2, 293-300, 2006. 
[21] D. Alic1. Development of an Attitude Scale Towards School: A Study on Reliability and Validity, Education and Science, Vol. 38, No. 168, 318-331.2013.

[22] J. D. Geddes, A. R. Murrell, J. Bauguss, J. Childhood learning: An examination of ability and attitudes toward school, Creative Education, Vol. 1, No. 03, 170-183, 2010.

[23] M. A. Gottfried. Evaluating the relationship between student attendance and achievement in urban elementary and middle schools: An instrumental variables approach, American Educational Research Journal, Vol. 47, No.2, 434-465, 2010.

[24] K. Marjoribanks. Family capital, children's individual attributes, and academic achievement, The Journal of Psychology, Vol. 126, No. 5, 529-538, 1992.

[25] H. Price. Being Happy is What Matters Most: A look at two high-achieving girls' learning experiences in the classroom, Psychoanalytic Studies, Vol. 2, No. 1, 51-64, 2000

[26] R. J. Sternberg, B. Torff, B., E. L. Grigorenko, E. L. Teaching triarchically improves school achievement, Journal of Educational Psychology, Vol. 90, No. $3,374-384.1998$

[27] T. Argon, D. C. Yilmaz. The relationship between high school students' peer relations and their attitude about school, Journal of Research in Education and Teaching, Vol. 5, Özel Say1, 250-258, 2016.

[28] M. Balkıs, G. Arslan, G. Psychometrics properties of school attitude assessment survey: A Study of Reliability and Validity, Ușak University Journal of Social Sciences, Vol. 9, No. 1, 1-16, 2016.

[29] A. Roy, J. Kareem, J. (2015). Attitude of public towards higher education: Conceptual analysis, Scholedge International Journal of Multidisciplinary \& Allied Studies, Vol. 2, No. 12, 19-28, 2015.

[30] M. Afzal, M, Rashid. Higher Education in Asian Context: A Study of Students' Attitude towards Higher Education in Pakistani Universities, Bulletin of Education and Research, Vol. 40, No.2, 137-145, 2018.

[31] M. Sheikh, S. A. K. Pramanik, M.E. Hossain. Students' Attitude towards Higher Education in Bangladesh: Comparison between Public and Private Universities, Journal of Hamdard University Bangladesh, Vol. 3, No. 1,159-172, 2016.

[32] A. Field, A. Discovering statistics using SPSS, London: SAGE, 2005.

[33] A. Bryman, D. Cramer. Quantitative data analysis with SPSS release 10 for Windows, London: Routledge, 200.

[34] R.C. MacCallum, K.F. Widaman, K. F., Zhang, S., \& Hong, S. Sample size in factor analysis, Psychological methods, Vol. 4, No. 1, 84-99, 1999.

[35] E. Tavşancıl. Tutumların ölçülmesi ve SPSS ile veri analizi [Measuring attitudes and data analysis with SPSS]. Nobel Yayınevi, Ankara, 2006.

[36] A. Erkuş. (2003). Psikometri üzerine yazılar[Articles on psychometrics], (1. Basım), Ankara: Türk Psikologlar Derneği Yayınları, pp. 34-158, 2003.

[37] G. Bohner, N. Dickel. Attitudes and attitude change, Annual review of psychology, No. 62, 391-417, 2011.

[38] R. Likert. A technique for the measurement of attitudes, Archives of psychology Vol. 22, No. 140, 55, 1932.

[39] I. Ajzen, M. Fishbein. Scaling and testing multiplicative combinations in the expectancy-value model of attitudes, Journal of Applied Social Psychology, Vol. 38, No. 9, 2222-2247, 2008.

[40] M. J. Allen, W. M. Yen. Introduction to measurement theory, Long Grove, IL, Waveland Press, 2002.

[41] A. Anastasi. Psychological testing (6th ed.), New York, Macmillan, 1988.

[42] C. H. Lawshe. A quantitative approach to content validity, Personnel psychology, Vol. 28, No. 4, 563-575, 1975.

[43] H. Yurdugül. (2005). Using content validity indexes for content validity in scale development studies, XIV. Ulusal Eğitim Bilimleri Kongresi, No. 1, 771-774, 2005.

[44] H. Şencan. H. Sosyal ve davranıșsal ölçümlerde güvenilirlik ve geçerlik[Reliability and validity in social and behavioral measurements], (1. Basım). Ankara: Seçkin Yayıncılık, 2005.

[45] J. W. Creswell, J. W. Educational research: Planning, conducting, and evaluating quantitative and qualitative research (Second edition), New Jersey: Pearson Education, Inc, 2005.

[46] Ş. Büyüköztürk. Questionnaire development, The Journal of Turkish Educational Sciences, Vol. 3, No. 2, 133-151, 2005.

[47] M.M. Yaşlıoğlu. Factor Analysis and Validity in Social Sciences: Application of Exploratory and Confirmatory Factor Analyses], Istanbul University Journal of the School of Business, No. 46(Special Issue), 74-85, 2017.

[48] İ. Yurdabakan, S. Cüm. Based on Explanatory Factor Analysis), Turkish Journal of Family Medicine and Primary Care, Vol. 11, No. 2, 108-126, 2017.

[49] B. G. Tabachnick, L. S. Fidell. Using multivariate statistics (5th ed.), Boston, MA: Allyn \& Bacon, 2007.

[50] H. F. Kaiser. An index of factorial simplicity, Psychometrika, Vol. 39, No. 1, 31-36, 1974.

[51] B. A. Cerny, H.F. Kaiser. A study of a measure of sampling adequacy for factor- analytic correlation matrices, Multivariate Behavioral Research, Vo1. 2, No. 1, 43-47, 1977. DOI: $10.1207 / \mathrm{s} 15327906 \mathrm{mbr} 12013$.

[52] Ö. Çokluk, G. Şekercioğlu, Ş. Büyüköztürk. Sosyal bilimler için çok değişkenli istatistik: SPSS ve LISREL uygulamaları [Multivariate statistics for social sciences: SPSS and LISREL applications], Ankara: Pegem, .2018.

[53] R. Ho. (2006). Handbook of univariate and multivariate data analysis and interpretation with SPSS, CRC Press, 2006.

[54] H. F. Kaiser \& J. Rice. Little Jiffy, Mark IV, Educational and Psychological Measurement, No. 34, 111-117, 1974.

[55] N. L. Leech, K. C. Barrett, G.A. Morgan, G. A. SPSS for intermediate statistics, Use and interpretation. (2. Bask1), New Jersey: Lawrence Erlbaum Associates, Inc, 2005.

[56] J. Pallant. SPSS Survival manual: A step by step guide to 
data analysis using SPSS for windows, (4rd ed.), McGraw Hill: Open University Press, 2011.

[57] Ş. Kalaycı. Çok değişkenli istatistik teknikleri (SPSS uygulamali) [Multivariate statistics techniques (SPSS applied)], Ankara: Asil Yayın Dağıtım, 2009.

[58] A. B. Costello, J. W. Osborne, J. W. Best Practices in Exploratory Factor Analysis: Four Recommendations for Getting the Most from Your Analysis, Practical Assessment Research \& Evaluation, Vol. 10, No. 7, 1-9, 2005.

[59] R. Kline. Principles and practice of structural equation modeling (2nd ed.), New York, NY: Guilford Press, 2005.

[60] E. K. Schermelleh, H. Moosbrugger. Evaluating the Fit of Structural Equation Models: Tests of Significance and Descriptive Goodness- of-Fit Measures, Methods of Psychological Research Online, Vol. 8, No. 2, 23-74, 2003.

[61] R. E. Schumacker, R.G. Lomax. A beginner's guide to structural equation modeling, London: Psychology Press, 2004.
[62] İ. Seçer. SPSS ve LISREL ile pratik veri analizi.[Practical data analysis with SPSS and LISREL], Ankara: An1 Yayınc1lık, 2015.

[63] P. Liu, P. Developing a scale to measure the interactivity of websites, Journal of Advertising Research, No. 43, 207-217, 2003.

[64] K. Özdamar. Paket Programlar İle İstatistiksel Veri Analizi. [Statistical Data Analysis with Package Programs] Eskișehir: Kaan Kitabevi. 1999.

[65] A. Adıgüzel. The validity and reliability study about school attitude scale, Electronic Journal of Social Sciences, Vol. 11, No. 40, 30-45, 2012.

[66] R. E. Petty, D.T. Wegener, L.R. Fabrigar. Attitudes and attitude change, Annual Review of Psychology, Vol. 48, No. 1, 609-647, 1997.

[67] S. T. Cheng, A. C. M. Chan, The Development of a Brief Measure of School Attitude. Educational and Psychological Measurement, Vol. 63, No. 6, 1060-1070, 2003. 